\title{
Pengaruh Silika Halus terhadap Ketahanan Mortar
}

\author{
W. Firmansyah, ${ }^{*}$ Widhya B, Suryadi, Wahyu B.W, Agus S.W, Alfian N., M. I. Amal, dan Nurul T.R. \\ Lab Material Lanjut dan Nanoteknologi, \\ Pusat Penelitian Fisika- LIPI \\ Kawasan PUSPIPTEK Serpong Tangerang 15314
}

Intisari

Penggunaan bahan bangunan beton dengan penambahan (aditif) mikrosilika atau silika telah diketahui merupakan salah satu alternatif untuk mendapatkan beton dengan kinerja yang tinggi, oleh karena itu penelitian ini bertujuan untuk mengetahui pengaruh penggunaan aditif silika pada mortar pada berbagai komposisi silika terhadap berat semen. Setelah itu kemudian diuji pengaruh penggunaan aditif silika pada mortar terhadap serangan $\mathrm{H}_{2} \mathrm{SO}_{4}$ dan $\mathrm{CH}_{3} \mathrm{COOH}$. Aditif silika yang digunakan yaitu mikrosilika impor dan bubuk silika hasil mechanical milling mineral alam. Sampel yang digunakan berdiameter 0,5 in dan tinggi $5 \mathrm{~cm}$. Sampel mortar ini kemudian diuji kuat patah, kuat tekan, densitas dan porositasnya. Berdasarkan hasil penelitian yang dilakukan, diketahui bahwa komposisi $10 \%$ bubuk silika terhadap berat semen merupakan komposisi silika yang optimal untuk memperkuat mortar. Hasil pengujian yang dilakukan juga menunjukkan bahwa bubuk silika memiliki peran yang sama dengan mikrosilika yaitu dapat meningkatkan ketahanan mortar terhadap serangan $\mathrm{H}_{2} \mathrm{SO}_{4}$ dan $\mathrm{CH}_{3} \mathrm{COOH}$ mencapai hampir sekitar 50\% dari mortar tanpa penggunaan aditif silika, sehingga bubuk silika ini memiliki peluang untuk menggantikan mikrosilika yang merupakan produk impor.

KATA KUNCI: mikrosilika, mechanical milling

\section{PENDAHULUAN}

Beton telah digunakan sebagai material konstruksi sejak dahulu. Namun demikian, dengan meningkatnya kebutuhan akan kekuatan bangunan, dibutuhkan beton yang mampu memenuhi kriteria untuk kebutuhan tersebut. Oleh karena itu, telah dikembangkan penggunaan zat aditif pozzolan, seperti mikrosilika, waterproofing, abu terbang, batu bara, polimer dan lain-lain $[1,2]$.

Penggunaan mikrosilika maupun bubuk silika diketahui dapat meningkatkan kekuatan beton, namun pada komposisi berapa dan sejauh mana ketahanannya terhadap serangan asam sulfat dan asam asetat belum banyak diketahui. Oleh karena itu, pada penelitian ini dibuat mortar dengan variasi tanpa zat aditif, dengan zat aditif berupa bubuk silika dan zat aditif mikrosilika dengan variasi 2,5\%,5\%,7,5\%, $10 \%, 12,5 \%, 15 \%, 20 \%$ dari berat semen. Pada komposisi yang menunjukkan nilai porositas terkecil kemudian direndam dalam dua larutan yang berbeda, yaitu larutan $\mathrm{H}_{2} \mathrm{SO}_{4}$ dan $\mathrm{CH}_{3} \mathrm{COOH}$, sehingga dapat diketahui sejauh mana pengaruh penggunaan aditif silika pada mortar tersebut terhadap serangan $\mathrm{H}_{2} \mathrm{SO}_{4}$ dan $\mathrm{CH}_{3} \mathrm{COOH}$.

Penelitian ini bertujuan untuk mengetahui komposisi silika optimal untuk meningkatkan kekuatan beton dan pengaruh penggunaan aditif silika (khususnya bubuk silika dari Lampung) pada mortar, terhadap serangan $\mathrm{H}_{2} \mathrm{SO}_{4}$ dan $\mathrm{CH}_{3} \mathrm{COOH}$

*E-MAIL: wahyufirmansyahdinasty@yahoo. com

\section{METODOLOGI PENELITIAN}

\section{A. Persiapan Sampel}

Batuan silika diambil dari provinsi Lampung (Gambar1.(a)) dan alat yang digunakan untuk membuat nanopartikel adalah Disk Mill dan Rotary Mill. Silika dimilling selama 500 jam. Bubuk silika hasil milling (Gambar 1.(b)) kemudian dianalisis ukurannya menggunakan SEM, dan didapatkan bubuk silika dengan ukuran beberapa nanometer.

Selain zat aditif, juga digunakan bahan pembuat beton,yaitu pasir, air, dan semen dengan rasio perbandingan pasir : air : semen sebesar $3: 0,6: 1$. Proses pembentukan sampel dilakukan dengan menggunakan alat cetak (paralon) dengan diameter 0,5 in dan tinggi $5 \mathrm{~cm}$, hal ini sesuai dengan standar pengujian kuat tekan, yaitu SNI 1974-1990-F [3], kemudian dijaga kelembabannya selama 28 hari.

\section{B. Pengujian Sampel}

1. Pengukuran Porositas dan Densitas Nilai porositas dan densitas dapat dihitung dengan persamaan sebagai berikut :

$$
\begin{array}{r}
\text { Porositas } \quad(\%)=\frac{B B-B K}{B B-B G-B K w} \times 100 \% \\
\text { Densitas, } \quad \rho=\frac{B K}{B B-B G-B K w} x 1
\end{array}
$$

dengan $\rho_{\text {air }}=1\left(\mathrm{gr} / \mathrm{cm}^{3}\right), \rho=$ densitas $\left(\mathrm{gr} / \mathrm{cm}^{3}\right)$, Berat Basah (BB), Berat Kering (BK), Berat Gantung (BG), dan Berat Kawat $(\mathrm{BKw})$, semua satuan berat dalam gram (gr). 


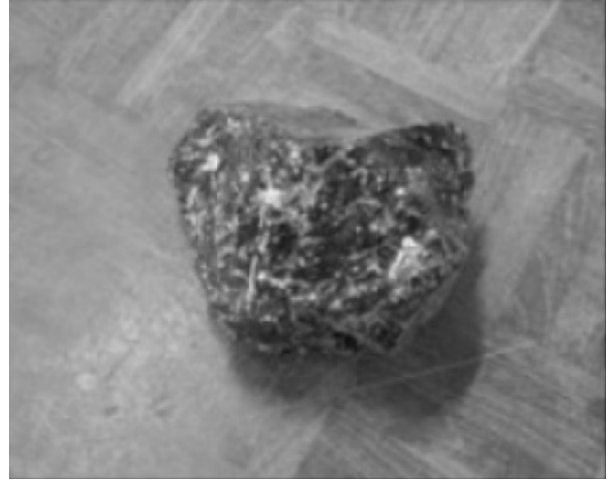

(a)

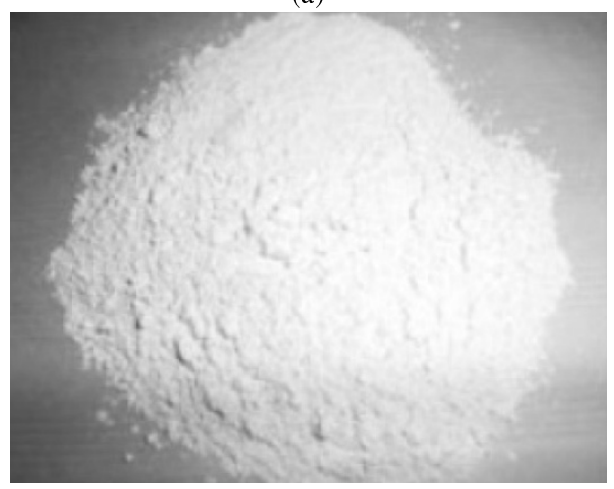

(b)

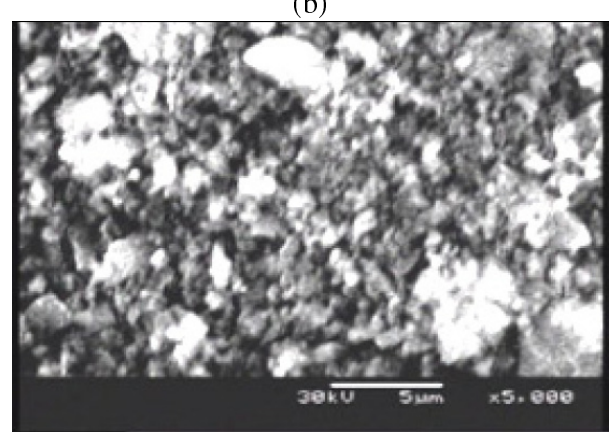

(c)

Gambar 1: (a). Batuan silika sebelum dimilling, (b). Bubuk silika hasil milling selama 500 jam, (c). Hasil SEM dari bubuk silika setelah dimilling.

\section{Pengujian Kuat Tekan (Compressive Strength)}

Kuat tekan (Compressive Strength) beton dapat dihitung dengan rumus sebagai berikut:

Compressive Strength $=$ Force $/$ Area

$$
\rho_{C S}=\frac{F}{A}
$$

dengan $\rho_{C S}=$ Kuat Tekan $(\mathrm{MPa}), \mathrm{F}=$ Gaya Tekan $(\mathrm{N})$, $\mathrm{A}=$ Luas Penampang $\left(\mathrm{cm}^{2}\right)$

3. Uji Patah (Bending Strength)

Kekuatan patah dari suatu bahan berbentuk silinder dapat dirumuskan sebagai berikut :

$$
\text { Kuat Patah }=\frac{8 P L}{\pi d^{3}}
$$

dengan $\mathrm{P}=$ Gaya pada puncak beban $(\mathrm{MPa}), \mathrm{L}=$ Jarak antar kedua tumpuan $(\mathrm{cm}), \mathrm{d}=$ Diameter benda uji $(\mathrm{cm})$

\section{HASIL DAN DISKUSI}

\section{A. Uji Porositas}

Berdasarkan penelitian yang dilakukan, diperoleh hasil pengujian porositas, pada beberapa komposisi silika seperti yang ditunjukkan pada Gambar 2.

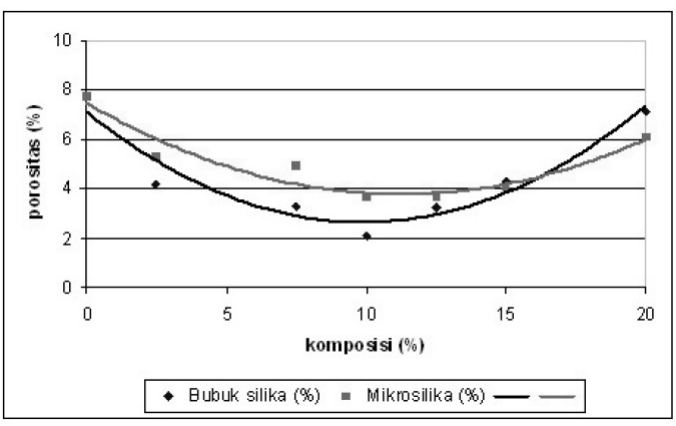

Gambar 2: Grafik porositas terhadap komposisi

Berdasarkan grafik diatas, dapat diketahui bahwa nilai porositas untuk sampel tanpa penambahan silika, nilainya sangat tinggi yaitu sebesar $7.77 \%$. Sedangkan untuk penambahan masing-masing $10 \%$ bubuk silika dan mikrosilika nilai porositasnya berturut-turut adalah 2,32 \% dan 3,012\%. Ini dapat dikatakan sebagai nilai optimal untuk nilai porositas pada bubuk silika dan mikrosilika, karena setelah penambahan pada komposisi $12,5 \%$ untuk bubuk silika dan mikrosilika nilai porositasnya naik kembali.

\section{Pengukuran Porositas dan Densitas Mortar Akibat Serangan Asam}

1. Nilai Porositas

Hasil uji porositas yang dilakukan pada mortar yang telah direndam dalam larutan $\mathrm{H}_{2} \mathrm{SO}_{4}$ dan $\mathrm{CH}_{3} \mathrm{COOH}$ selama 21 hari ditunjukkan pada Gambar 3.

Berdasarkan dua buah grafik diatas dapat dilihat bahwa nilai porositas makin besar seiring dengan makin lamanya waktu perendaman, namun nilai porositas untuk untuk mortar yang ditambahkan bubuk silika atau mikrosilika memiliki nilai porositas yang lebih kecil dibandingkan dengan mortar yang tidak ditambahkan dengan zat aditif. Secara fisik bahan bubuk silika atau mikrosilika ini akan mengisi setiap celah yang ada di dalam beton, sehingga mengakibatkan diameter pori mengecil dan total volume pori juga berkurang, dan secara kimia bahan mikrosilika ini bersifat pozolan, di mana mikrosilika ini bereaksi dengan $\mathrm{Ca}(\mathrm{OH})_{2}$ yang dilepas langsung dari semen.

2. Nilai Densitas

Hasil uji densitas yang dilakukan pada mortar yang 


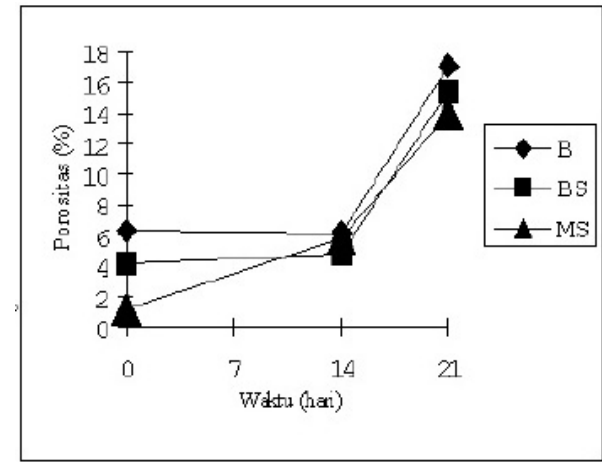

(a)

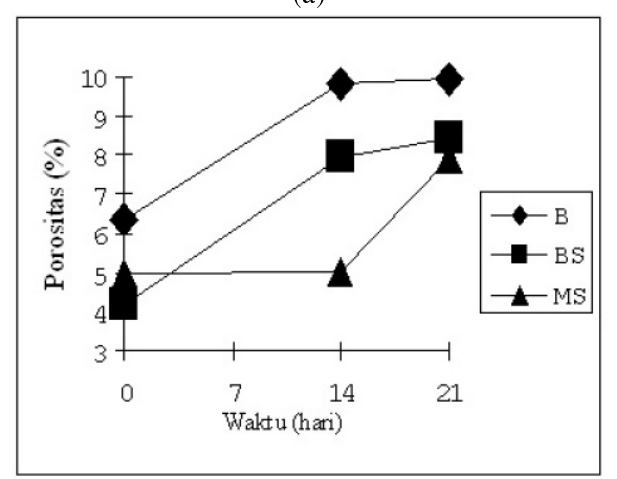

(b)

Gambar 3: Grafik hasil uji porositas mortar beton yang telah direndam dalam (a). $\mathrm{H}_{2} \mathrm{SO}_{4}$ dan (b). $\mathrm{CH}_{3} \mathrm{COOH}$

telah direndam dalam larutan $\mathrm{H}_{2} \mathrm{SO}_{4}$ dan $\mathrm{CH}_{3} \mathrm{COOH}$ selama 21 hari ditunjukkan pada Gambar 4.

Nilai densitas pada mortar dengan mikrosilika lebih besar daripada nilai densitas pada mortar dengan bubuk silika dan mortar biasa, dan nilai densitas pada mortar dengan bubuk silika lebih besar daripada nilai densitas pada mortar biasa. Hal ini terjadi karena partikel nano dari mikrosilika dan bubuk silika berekspansi masuk ke dalam pori-pori mortar sehingga membuat mortar menjadi lebih padat.

\section{B. Uji Kuat Tekan}

Pada penelitian ini, uji kuat tekan hanya dapat dilakukan pada mortar yang direndam dalam larutan $\mathrm{CH}_{3} \mathrm{COOH}$, sedangkan pada mortar yang direndam dalam larutan $\mathrm{H}_{2} \mathrm{SO}_{4}$ tidak dapat dilakukan uji kuat tekan, hal ini dikarenakan sampel mortar yang direndam dalam $\mathrm{H}_{2} \mathrm{SO}_{4}$ habis terkikis, sehingga tidak dapat dilakukan uji kuat tekan. Hal ini menunjukkan bahwa $\mathrm{H}_{2} \mathrm{SO}_{4}$ memiliki pengaruh lebih besar sebagai penghancur terhadap ketahanan mortar daripada $\mathrm{CH}_{3} \mathrm{COOH}$. Hal ini disebabkan $\mathrm{H}_{2} \mathrm{SO}_{4}$ merupakan asam yang lebih kuat dibandingkan dengan $\mathrm{CH}_{3} \mathrm{COOH}$. Hasil uji kuat tekan yang dilakukan pada mortar yang telah direndam dalam $\mathrm{CH}_{3} \mathrm{COOH}$ selama 21 hari ditunjukkan pada Gambar 5 .

Berdasarkan grafik di atas dapat dilihat bahwa nilai kuat

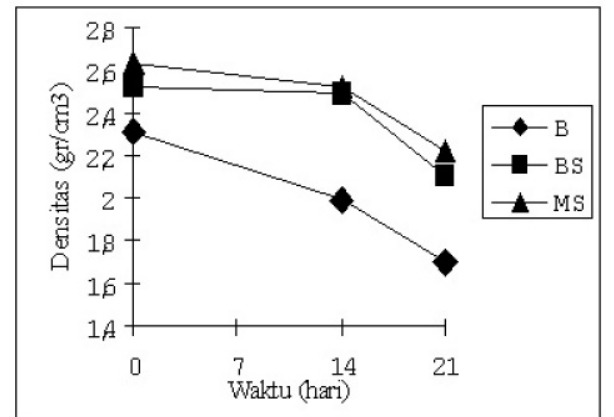

(a)

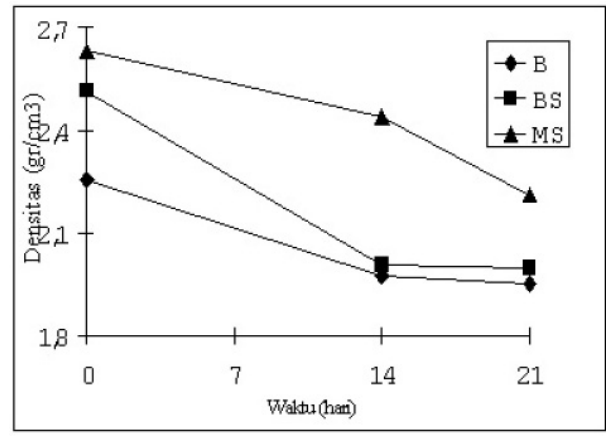

(b)

Gambar 4: Grafik hasil uji densitas mortar beton yang telah direndam dalam (a). $\mathrm{H}_{2} \mathrm{SO}_{4}$ dan (b). $\mathrm{CH}_{3} \mathrm{COOH}$

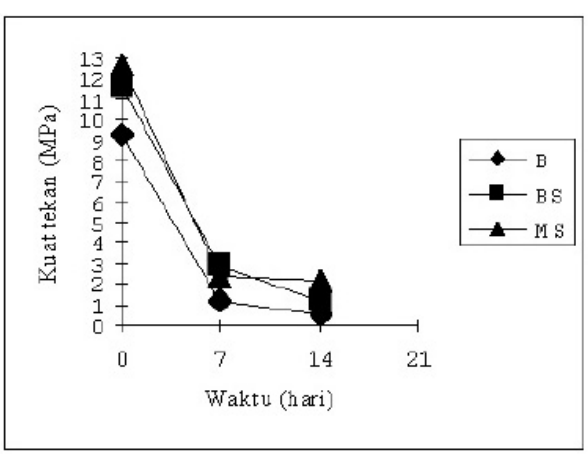

Gambar 5: Grafik hasil uji kuat tekan mortar beton yang telah direndam dalam $\mathrm{CH}_{3} \mathrm{COOH}$

tekan makin berkurang dengan makin lamanya waktu perendaman dalam $\mathrm{CH}_{3} \mathrm{COOH}$, namun nilai kuat tekan untuk mortar yang ditambah zat aditif (bubuk silika atau mikrosilika) lebih besar dari mortar tanpa penambahan zat aditif. Hal ini menjadi bukti bahwa terjadi penguatan pada mortar yang ditambahkan zat aditif.

\section{Uji Kuat Patah}

Hasil uji kuat patah yang dilakukan pada mortar yang telah direndam dalam larutan $\mathrm{H}_{2} \mathrm{SO}_{4}$ dan $\mathrm{CH}_{3} \mathrm{COOH}$ selama 21 hari ditunjukkan pada Gambar 6.

Berdasarkan dua grafik di atas dapat dilihat bahwa nilai 


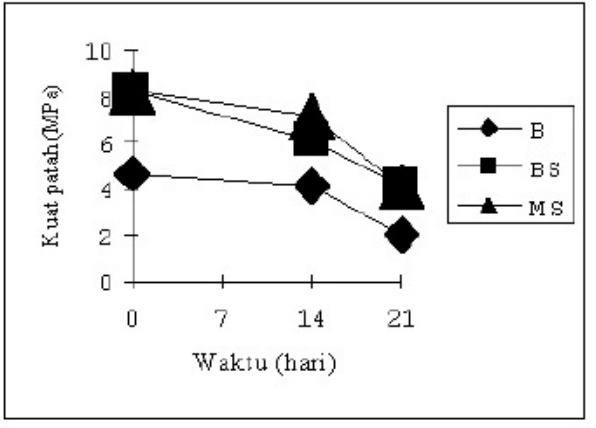

(a)

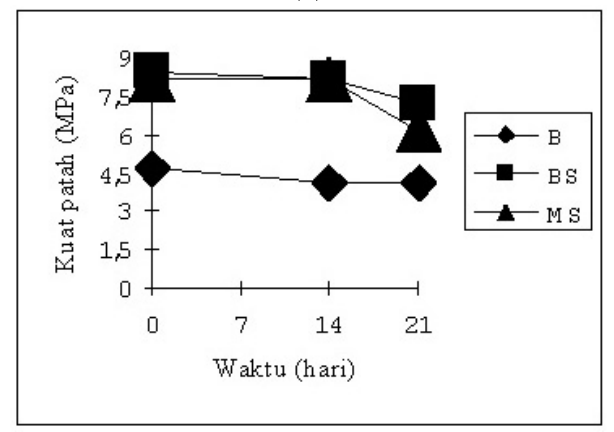

(b)

Gambar 6: Grafik hasil uji kuat patah mortar beton yang telah direndam dalam (a). $\mathrm{H}_{2} \mathrm{SO}_{4}$ dan (b). $\mathrm{CH}_{3} \mathrm{COOH}$

kuat patah mortar makin berkurang dengan makin lamanya waktu perendaman, namun dengan penambahan zat aditif (bubuk silika atau mikrosilika) penurunan nilai kuat patah mortar tidak signifikan seperti pada mortar tanpa penambahan zat aditif. Hal ini menunjukkan terjadi penguatan pada mortar akibat penambahan zat adtif.

\section{SIMPULAN}

Berdasarkan hasil penelitian Pengaruh Silika halus terhadap Ketahanan Mortar, dapat ditarik kesimpulan :
1. Nilai porositas dengan tambahan bubuk silika yang terendah yaitu pada komposisi $10 \%$ dengan nilai sebesar $2.32 \%$. Dan untuk penambahan mikrosilika nilai porositas yang terendah yaitu pada komposisi $10 \%$ dengan nilai sebesar $3.01 \%$. Sedangkan untuk mortar dengan tanpa penambahan bubuk silika atau mikrosilika nilai porositasnya jauh lebih tinggi yaitu sebesar $7.77 \%$.

2. Nilai densitas untuk mortar yang telah direndam dalam $\mathrm{H}_{2} \mathrm{SO}_{4}$ dan $\mathrm{CH}_{3} \mathrm{COOH}$, makin kecil dengan semakin lamanya waktu perendaman. Hal tersebut berasosiasi dengan kenaikan porositas seiring makin lamanya waktu perendaman. Mortar dengan penambahan mikrosilika dan bubuk silika memiliki nilai densitas dan porositas yang lebih baik dibanding dengan mortar tanpa penambahan zat aditif.

3. Nilai kuat tekan dan kuat patah pada mortar yang telah direndam dalam larutan $\mathrm{CH}_{3} \mathrm{COOH}$ maupun $\mathrm{H}_{2} \mathrm{SO}_{4}$ makin menurun dengan semakin lamanya waktu perendaman. Namun mortar dengan penambahan mikrosilika dan bubuk silika memiliki nilai kuat tekan dan kuat patah yang lebih baik dibanding dengan mortar tanpa penambahan zat aditif.

4. $\mathrm{H}_{2} \mathrm{SO}_{4}$ memiliki pengaruh lebih besar sebagai penghancur terhadap ketahanan mortar daripada $\mathrm{CH}_{3} \mathrm{COOH}$. Hal ini disebabkan $\mathrm{H}_{2} \mathrm{SO}_{4}$ merupakan asam yang lebih kuat dibandingkan dengan $\mathrm{CH}_{3} \mathrm{COOH}$.

5. Bubuk silika memiliki peran yang sama dengan mikrosilika, karena dapat meningkatkan ketahanan beton terhadap serangan $\mathrm{H}_{2} \mathrm{SO}_{4}$ dan $\mathrm{CH}_{3} \mathrm{COOH}$, sehingga bubuk silika ini memilki peluang untuk mengganti mikrosilika sebagai zat aditif untuk mendapatkan mutu beton yang baik.
[1] Elkem, M., How to Improve to Strength And Durability of Concrete, Elkem Material Available : [www.concrete.elkem.com]

[2] Segel R., Kole P., Kusuma G. , Pedoman Pengerjaan Beton (Berdasarkan SKSNI T-15-1991-03), Penerbit Erlangga, Jakarta(1994)

[3] Nadhiroh, M. , 'Beton Mutu Tinggi Menggunakan Silicafume/Mikrosilica', Jurnal Penelitian Pemukiman, Vol.X, pp .12(1994)

[4] Hayati, K. , 'Pengaruh Variasi Penambahan Bubuk Silika Terhadap Kekuatan Mortar', hasil penelitian mahasiswa USU di P2F LIPI, Serpong(2005).

[5] Hidayat, L., Peningkatan Kinerja Beton Dengan Mikrosilica,
Puslitbang Prasarana Transportasi Balai Jembatan dan Bangunan Pelengkap Jalan (2004).

[6] Mulyono, T., Teknologi Beton, edisi ke-1, Penerbit Andi, Yogyakarta(2003).

[7] Nadhiroh M.,Andriati A. H., Lasino , 'Penggunaan Silicafume/Mikrosilica Sebagai Bahan Tambahan Untuk Beton Mutu Tinggi', Makalah Seminar Sehari Mikrosilica Concrete The Choice For High Performance \& Long Service Life(2004).

[8] Supartono F.X. , 'Pengaruh Penambahan Mikrosilica Pada Peningkatan Ketahanan Beton Terhadap Korosi Sulfat', Seminar Haki, Jakarta(1992). 